\title{
Investigation on the Influence of Leadership Styles on Students' Academic Performance in Selected Secondary Schools: A Case Study of Gasabo District, Kigali, Rwanda
}

\author{
Mr. Harerimana Jean Paul ${ }^{1}$, Ms. Adegoke Oyebimpe Toyin ${ }^{2}$ \\ ${ }^{1}$ Dean, School of Education, Mount Kenya University Rwanda, P.O.BOX 5826 Kigali, Rwanda \\ ${ }^{2}$ Head of department, Psychology, Mount Kenya University Rwanda, P.O.BOX 5826 Kigali
}

\begin{abstract}
This study entitled 'Investigation on the Influence of Leadership Styles on Students' Academic Performance in Selected Secondary Schools: A Case Study of Gasabo District, Kigali, Rwanda aims at assessing the impact of leadership styles on academic performance of students in secondary schools located in Gasabo District, Kigali, Rwanda. The study followed descriptive surveydesign. The study revealedthat democratic leadership style was highly applied than the remaining leadership styles because its average mean is 3.49 which is interpreted as high mean while others are used moderately. It was also revealed that in selected schools they perform moderately in general but it was revealed that students hold the character of competitiveness among themselves. Finally correlation results revealed that there is a positive relationship of 0.332 between transformational leadership style and performance of students but statistically significant as it is 0.002, positive relationship also was found between democratic style and performance of students of 0.067 but are not statistically significant as it was 0.550 , and a negative relationship which is not statistically significant was found between two remaining leadership styles meaning autocratic and laissez-faire and academic performance in selected schools. It was recommendedthat Head teachers should improve their way in transformational leadership style since it was found as the best factor of student performance.
\end{abstract}

Keywords: Authoritative, democratic, laissez-faire, and transformational leadership styles

\section{Introduction}

Armstrong (2004) defines leadership as influence, power and the legitimate authority acquired by a leader to be able to effectively transform the organization through the direction of the human resources that are the most important organizational asset, leading to the achievement of desired purpose. Moreover, Cole (2002) defines leadership as inspiring people to perform. Even if an institution has all the financial resources to excel, it may fail dismally if the leadership does not motivate others to accomplish their tasks effectively. The quality of the school in any given nation is affected by how the internal processes work to constantly improve its performance thus head teachers are faced with the task of increasing student achievement while maintaining order through acceptable student behavior which may require changing school performance (Tableman, 2004).

Students' academic achievement is very crucial at every level; from a perspective of an individual, a family, an organization (like a school) and the nation as a whole. For a school to perform well both in academics and in co-curricular activities, effective leadership is needed.(Cole, 2004). Sheikh (2001) described a leader as a person who motivates a group of people to achieve its tasks and maintain team unity throughout the process. Also, Schermerhorn, Hunt and Osborn (2000) define leadership as a case of interpersonal influence that get individuals, or groups of people to do what the leader wants to be done. A leader unifies, embodies the opinion of the people to any desired goals. According to Sushila (2004), the head teacher is the leader in a school, the pivot around which many aspects of the school revolve, and the person in charge of every detail of the running of the school; academic or administrative. Likewise, Finn (2002) maintains that the most important thing to an organization is thequality of its leadership, particularly the quality of the headteacher in a school setting. Inthis context, Hurley (2001) upholds that the headteacher is the answer to a school's general development and improvement of academic performance, in that an effective headteacher creates an environment that stimulates an enthusiasm for learning.

Wilmore (2002) further states that head teachers play diverse roles: they are responsible for effecting education policy, keeping track of all activities within the school and ensuring that their schools run smoothly. Sashkin and Sashkin (2003) maintain that leadership matters becauseleaders help reduce ambiguity and uncertainty in organizations or society. Leaders take constructive acts to achieve long-term goals and provide clear positive reasons for their actions, goals, and accomplishments. It is important for him/her therefore to adopt an administrative style that will nurture, inspire and sustain an enabling environment for academic excellence. Leadership style is a key factor to improve the condition of any department and also the same in school aspects. Functional schools and outstanding performance thus do not exist without effective leadership 
style. The leadership style of the head teacher is of utmost importance in the school performance. Kendra (2011) cites leadership styles as the characteristic that critically define the leaders in organizations. He further stresses that, leadership styles are mix- and - match of various traits and will in some way influence the culture of the whole organization.

Different experts have identified different leadership styles with distinctive characteristics. For example (Avolio and Bass, 2002) presented full range leadership theory according to which three leadership styles known as transactional, transformational, laissez-fair were identifiedwhile Omolayo (2009) identified three more head teacher leadership styles including laissez-faire. They are autocratic, democratic, and laissez-faire. Mwalala, (2008) observes that authoritarian is a harsh climate leads to poor performance of students. Laissezfaire leadership style may result in indiscipline due to non-enforcement of rules and regulations in a school leading to poor performance.A democratic style is characterized by co-ordination, co-operation and by collaboration. Yulk (2005) discovered that autocratic leadership style allows no participation in decision and laissez-faire which is also known as free-rein leadership style empowers subordinate to work with freedom and free-will.

Kabuchi and Gitau (2010) on their studies on influence of head teachers' leadership style on pupils' performance in Kenyan public primary schools found out that, there was significant relationship between head teachers' leadership styles and pupils' academic performance. Further these researchers found that, democratic leadership style was the most widely practiced followed by Laissez- faire and finally autocratic. In Rwanda, a recent study conducted by Nganizi (2015) in Kicukiro in Nine Years Basic Education found that schools with democratic leadership styles perform better than other schools. However, this study explored the impact of leadership style adopted by head teachers in public schools of Gasabo district on performance of students.

\subsection{Statement of the Problem}

Performance in secondary school has been mentioned to be low. This could be linked to the deprived school leadership styles utilized in secondary schools. Given the importance attached to education, every district in Rwanda is striving to improve on the quality of education and students' academic achievement. Nonetheless, Statistics by REB (2012) show that, some schools especially those having 9 and 12 YBE program perform poorly in national examinations at ordinary level while others perform well. The majority of Students in Gasabo district have been performing poorly over the last three years. In the past five years Students' performance in the schools has been deteriorating. While a few Students excel in their examinations, the majority perform poorly (Gasabo District Education Office, 2013). It is generally believed that students' poor performance is due to head teachers' leadership styles. So, improving learning outcomes requires an approach to leadership development, which focuses on leadership styles. This means attempting to change the mind-set of leaders to regard the processes of teaching and learning as central to their role rather than simply leaving such matters to teachers, Bush and Bell ( 2007). This study therefore investigated the effects of leadership styles of school head teachers on students' performance in selected public secondary schools within Gasabo district.

\section{The Purpose}

The general objective of this research was to investigate the relationship between leadership styles adopted by head teachers in Gasabo district on academic performance of students.

\subsubsection{Specific Objectives}

This study was guided by the following objectives:

1) To find out the leadership styles adopted by head teachers of public secondary school in Gasabo district;

2) To analyze the students' academic performance in public secondary school of Gasabo District, KigaliRwanda;

3) To investigate the relationship between Head teachers' leadership styles and students' academic performance in public secondary school of Gasabo District, Kigali-Rwanda.

\subsection{Conceptual frame work}

Mutai (2000) argues that conceptual framework is the relationship between variables in a study showing them graphically and diagrammatically. The purpose is to help the reader quickly see the proposed relationship of concepts, Orodho (2004).The conceptual framework in this study based on effect of leadership styles on students' academic performance. The main variables that influence academic performance include head teachers' leadership styles, school plant and resources and students behavior. 


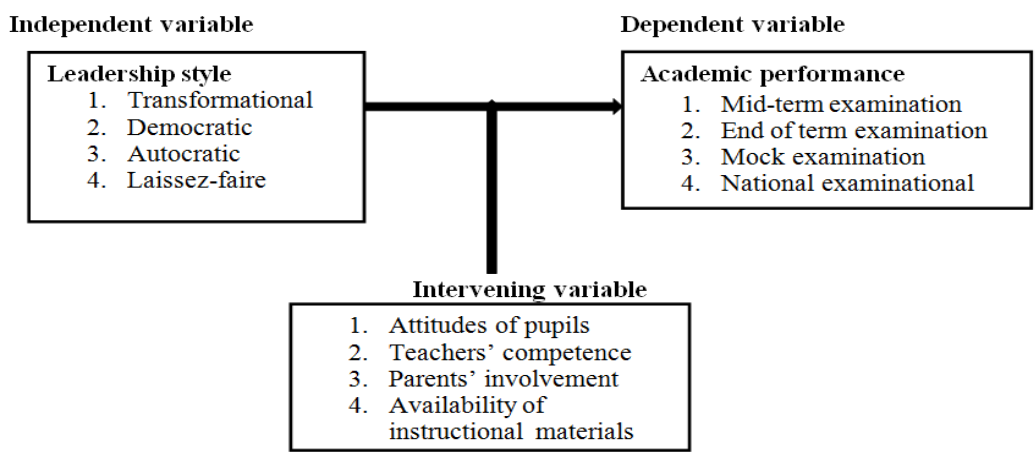

According to the above diagram this study will explore the relationship between leadership styles as independent variable where only four kind of leadership style were regarded and academic performance as dependent variable which is explained by school examinations results, mock examination, and national examination.

\section{Research Design}

The study uses the descriptive survey design

\section{Population and Sample size distribution}

Table1: Total population Sample size

\begin{tabular}{|c|c|c|}
\hline School & Head teachers Teachers & Head teachers Teachers \\
\hline Musave & 1361 & \\
\hline Gikomero & 1421 & \\
\hline Bumbogo & 14018 & \\
\hline Kimironko 1 & 1361 & \\
\hline Kagugu & $1711 \quad 15$ & \\
\hline Kinyinya & 14518 & \\
\hline Ndera & 155111 & \\
\hline Gasogi & 13818 & \\
\hline Kabuga & 168 & 12 \\
\hline Total & 9431 & \\
\hline
\end{tabular}

Source: Researcher, 2016

\section{Research Findings}

Extent of influence of transformational leadership style in selected schools

Transformational leadership happens when leader become wider and uphold the interests of the employees, once they generate awareness and acceptance for the purpose and assignment of the group, so when they blend employees to appear beyond their own self-interest for the good of the group (Bass, 1993). Transformational leadership style is well implemented when the leader holds inspiration motivation to people under his or her management, intellectual simulation and individual consideration. Here in this study, participants were pleased to provide the opinions on each indicator of transformational leadership style.

Table 2: Opinions of respondents on inspirational motivation from head teachers

\begin{tabular}{|c|c|c|c|c|c|c|}
\hline \multirow{4}{*}{\begin{tabular}{|l|} 
Inspirational motivation \\
The head teacher creates a clear \\
vision of the future of the \\
School \\
The head teacher inspires \\
confidence in the value of his \\
argument
\end{tabular}} & Strongly disagree & Disagree & Not sure & Agree & Stronglyagree & Mean \\
\hline & & & & & & 2.36 \\
\hline & $(11.1 \%)$ & $(49.4 \%)$ & $(32.1 \%)$ & $(7.4 \%)$ & $\ldots$ & 2.04 \\
\hline & $\begin{array}{l}19 \\
(23.5 \%)\end{array}$ & $\begin{array}{l}43 \\
(53.1 \%)\end{array}$ & $\begin{array}{l}16 \\
(19.8 \%)\end{array}$ & $\begin{array}{l}3 \\
(3.7 \%)\end{array}$ & $\ldots$ & 2.02 \\
\hline $\begin{array}{l}\text { The head teacher is eager to achieve } \\
\text { the vision of this school }\end{array}$ & & & & & & \\
\hline $\begin{array}{l}\text { The head teacher sets an enviable } \\
\text { example for others to follow }\end{array}$ & $\begin{array}{l}27 \\
(33.3 \%)\end{array}$ & $\begin{array}{l}31 \\
38.3\end{array}$ & $\begin{array}{l}17 \\
21.0\end{array}$ & $\begin{array}{r}6 \\
7.4\end{array}$ & -- & 2.53 \\
\hline $\begin{array}{l}\text { The head teacher demonstrates high } \\
\text { personal standards }\end{array}$ & $\begin{array}{l}9 \\
1(1.1 \% 0\end{array}$ & $\begin{array}{l}32 \\
(39.5 \%)\end{array}$ & $\begin{array}{l}30 \\
(37.0 \%)\end{array}$ & $\begin{array}{l}8 \\
(9.9 \%)\end{array}$ & $\begin{array}{l}2 \\
(2.5 \%)\end{array}$ & 2.85 \\
\hline \multirow[t]{2}{*}{$\begin{array}{l}\text { The head teacher motivates school } \\
\text { team including students }\end{array}$} & & $\begin{array}{l}28 \\
(34.6 \%)\end{array}$ & $\begin{array}{l}29 \\
(35.8 \%)\end{array}$ & $\begin{array}{l}16 \\
(19.8 \%)\end{array}$ & $\begin{array}{l}4 \\
(4.9 \%)\end{array}$ & \\
\hline & $\begin{array}{l}10 \\
(12.3 \%)\end{array}$ & $\begin{array}{l}12 \\
(14.8 \%)\end{array}$ & $\begin{array}{l}18 \\
22.2\end{array}$ & $\begin{array}{l}34 \\
(42 \%)\end{array}$ & $\begin{array}{l}7 \\
8(.6 \%)\end{array}$ & 3.20 \\
\hline Average & & & & & & 2.50 \\
\hline
\end{tabular}

Source: Primary data2016

Legend: 5. Strongly Agree=[4.21-500] =very high, 4. Agree $=[3.41-4.20]=$ high, 3. Not Sure= $[2.61-3.40]$ $=$ Moderate, 2. Disagree $=[1.81-2.60]=$ low 1. Strongly Disagree $=[1.00-1.80]=$ very low 
Table2 shows the opinions of participants in this study on the ability of head-teachers on inspirational motivation which is the part of transformational leadership style. The inspirational motivation according to the opinions of respondents is averagely perceived on two indicators namely demonstration of high personal standard on the mean of 2.85 which is interpreted as moderate mean and resulting from the high number of participants who have been not sure on the percentage of $35.8 \%$. Secondly it was revealed that the head teachers from schools which were visited in this study use to motivate school team including students on the mean of 3.20 which is interpreted as moderate mean. The remaining indicators of inspirational motivation were rated lowly and very lowly and this influenced the average mean to 2.50 which falls in the interval of [1.812.60] which is interpreted as low mean it means that the way head teachers inspire and motivate their people is critical and is not well perceived by participants in this study.

Table3: Opinions of respondents on the ability of intellectual stimulation among head teachers

\begin{tabular}{|c|c|c|c|c|c|c|}
\hline Intellectual simulation & Stronglydisagree & Disagree & Not sure & Agree & Stronglyagree & Mean \\
\hline \multirow{4}{*}{$\begin{array}{l}\text { The head teacher asks questions to test } \\
\text { other's thinking } \\
\text { The head teacher encourages other to } \\
\text { challenge his status quo } \\
\text { The head teacher provides tasks that are } \\
\text { stretching but achievable } \\
\text { The head teacher shows the ability to } \\
\text { exploit the benefit of new ideas } \\
\text { The head teacher encourages others to re- } \\
\text { think their ideas }\end{array}$} & \begin{tabular}{l|l}
$\mathrm{t}$ & 24 \\
& $(29.6 \%)$
\end{tabular} & $\begin{array}{l}43 \\
(53.1 \%)\end{array}$ & $\begin{array}{l}10 \\
(12.3 \%)\end{array}$ & $\begin{array}{l}2 \\
(2.5 \%)\end{array}$ & $\begin{array}{l}2 \\
(2.5 \%)\end{array}$ & 1.95 \\
\hline & 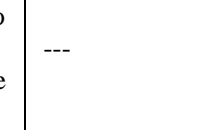 & $\begin{array}{l}11 \\
(13.6 \%)\end{array}$ & $\begin{array}{l}28 \\
(34.6 \%)\end{array}$ & $\begin{array}{l}28 \\
(34.6 \%)\end{array}$ & $\begin{array}{l}14 \\
(17.3 \%)\end{array}$ & 3.56 \\
\hline & $\begin{array}{l}3 \\
(3.7 \%)\end{array}$ & $\begin{array}{l}19 \\
(23.5 \%)\end{array}$ & $\begin{array}{l}29 \\
(35.8 \%)\end{array}$ & $\begin{array}{l}27 \\
(33.3 \%)\end{array}$ & $\begin{array}{l}3 \\
(3.7 \%)\end{array}$ & 3.10 \\
\hline & --- & $\begin{array}{l}8 \\
(9.9 \%)\end{array}$ & $\begin{array}{l}39 \\
(48.1 \%)\end{array}$ & $\begin{array}{l}27 \\
(33.3 \%)\end{array}$ & $\begin{array}{l}7 \\
(8.6 \%)\end{array}$ & 3.41 \\
\hline & $\begin{array}{l}5 \\
(6.2 \%)\end{array}$ & $\begin{array}{l}31 \\
(38.3 \%)\end{array}$ & $\begin{array}{l}31 \\
(38.3 \%)\end{array}$ & $\begin{array}{l}14 \\
(17.3 \%)\end{array}$ & --- & 2.67 \\
\hline
\end{tabular}

Source: Primary data2016

Legend: 5. Strongly Agree=[4.21-500] =very high, 4. Agree $=[3.41-4.20]=$ high, 3. Not Sure= $[2.61-3.40]$ $=$ Moderate, 2. Disagree $=[1.81-2.60]=$ low 1. Strongly Disagree $=[1.00-1.80]=$ very low

The table 3 shows the opinions of respondents on intellectual simulation capability of head teachers of selected schools in this study. Two of all indicators for intellectual simulation were positively appreciated by respondents in this study. Those are encouraging school members to criticize their status -quo on the mean of 3.56 which is interpreted as high mean since it falls in the interval of [3.41-4.20] and this is resulting from $34.6 \%$ of respondents who reported that they do agree with that and $17.3 \%$ of respondents who have strongly agreed. Secondly, respondents reported that the head teachers show the ability of exploiting new constructive ideas from schools members even if outside of the schools on the mean of 3.41 which is interpreted as high mean. Two of remaining variables were rated moderately because their means fallen in the interval of [2.613.40] which is interpreted as moderate mean; those are providing schools members tasks that are stretching but achievable and encouraging others to rethink their ideas. The remaining variable was negatively appreciated by respondents on the mean of 1.95 which is interpreted as low mean that is asking questions in order to test the thinking capability of school members including teachers and students. To this sub- indicator of transformation leadership; the average mean of 2.93 and which is interpreted as moderate mean showing that the head teachers of surveyed schools apply it in moderate way meaning neither good nor bad. For example one of the interviewed head teacher when asked whether he holds professional development workshops in his school he said that the government does not provide funds for such workshops which indicates that the head teacher does not improvise and see that his staff is growing professionally.

Table 4: Opinions of respondents on individual consideration of head-teachers

\begin{tabular}{|c|c|c|c|c|c|c|}
\hline Individualconsideration & Stronglydisagree & Disagree & Not sure & Agree & Stronglyagree & Mean \\
\hline $\begin{array}{l}\text { The head teacher treats people as unique } \\
\text { individuals in this school }\end{array}$ & $\begin{array}{l}3 \\
(3.7 \%) \\
\end{array}$ & $\begin{array}{l}20 \\
(24.7 \%)\end{array}$ & $42(51.9 \%)$ & $\begin{array}{l}14 \\
(17.3 \%)\end{array}$ & 2 & 2.90 \\
\hline $\begin{array}{l}\text { The head teacher tries to understand the } \\
\text { other person's view point }\end{array}$ & $\begin{array}{l}21 \\
(25.9 \%)\end{array}$ & $\begin{array}{l}35 \\
(43.2 \%)\end{array}$ & $\begin{array}{l}9 \\
(11.1 \%)\end{array}$ & $\begin{array}{l}10 \\
(12.3 \%)\end{array}$ & $\begin{array}{l}6 \\
(7.4 \%)\end{array}$ & 2.32 \\
\hline $\begin{array}{l}\text { The head teacher builds co-operative } \\
\text { relationship with immediate colleagues } \\
\text { The head teacher recognizes the different } \\
\text { capabilities of individuals }\end{array}$ & -- & $\begin{array}{l}34 \\
(42.0 \%)\end{array}$ & $\begin{array}{l}29 \\
(35.8 \%)\end{array}$ & $\begin{array}{l}13 \\
(16.0 \%)\end{array}$ & $\begin{array}{l}5 \\
(6.2 \%)\end{array}$ & 2.86 \\
\hline Average & $\begin{array}{l}10 \\
(12.3 \%)\end{array}$ & $\begin{array}{l}29 \\
(35.8 \%)\end{array}$ & $\begin{array}{l}16 \\
(19.8 \%)\end{array}$ & $\begin{array}{l}21 \\
(25.9 \%)\end{array}$ & $\begin{array}{l}5 \\
(6.2 \%)\end{array}$ & $\begin{array}{l}2.78 \\
\mathbf{2 . 7 1}\end{array}$ \\
\hline
\end{tabular}

Source: Primary data2016

Legend: 5. Strongly Agree $=[4.21-500]=$ very high, 4. Agree $=[3.41-4.20]=$ high, 3. Not Sure $=[2.61-3.40]$

$=$ Moderate, 2. Disagree $=[1.81-2.60]=$ low 1 . Strongly Disagree $=[1.00-1.80]=$ very low 
Table 4 shows the opinions of respondents on how head teachers consider other individuals at their school. Three of four indicators which were considered on this sub-indicator were rated moderately since their means fall in the interval of [2.61-3.40] which is interpreted as moderate mean. Those sub-indicators are treating people in unique way, building cooperative relationship with immediate colleagues and recognizing different capabilities of individuals at schools. Lastly respondents provided that there is low understanding of the viewpoints of other persons on the mean of 2.32 which is interpreted as low mean. The average mean shows that head teachers fulfill this principle on the average rate where the overall mean is 2.71 which is interpreted as high mean.

The transformational leadership style holds the overall mean which is equal to $(2.50+2.93+2.71) / 3$. This gives2.71which can be interpreted as moderate mean. This leads to the conclusion of saying that in surveyed schools. In this study, transformational leadership style is neither highly applied nor lowly used for managing schools, most head teachers were not having vision and mission and strategic direction of their schools; when interviewed they all seemed not even to understand what it meant.

\section{Extent of influence of democratic leadership style in selected schools}

Democratic leadership refers to a situation where there is equal work among leaders and followers. According to Goldman (2002), democratic organizations typically have the following six characteristics: policies are determined by a group of organizations, technical and job performance measures are discussed so they are understood by all, leaders provide advice to members in regards to implementing tasks, members are free to choose with whom they work, the group determines the distribution of tasks, and leaders try to be objective in giving praise and criticism. Goldman (2000) states that leaders using a democratic style of leadership build consensus through participation, but these leaders also expect a higher level of excellence and self-direction. In this study various statement which related to leadership styles and related to what is written above were considered and participants were used to provide their opinions about democratic situation in their schools

Table 5: Opinions of respondent on the way by which democratic principles are applied

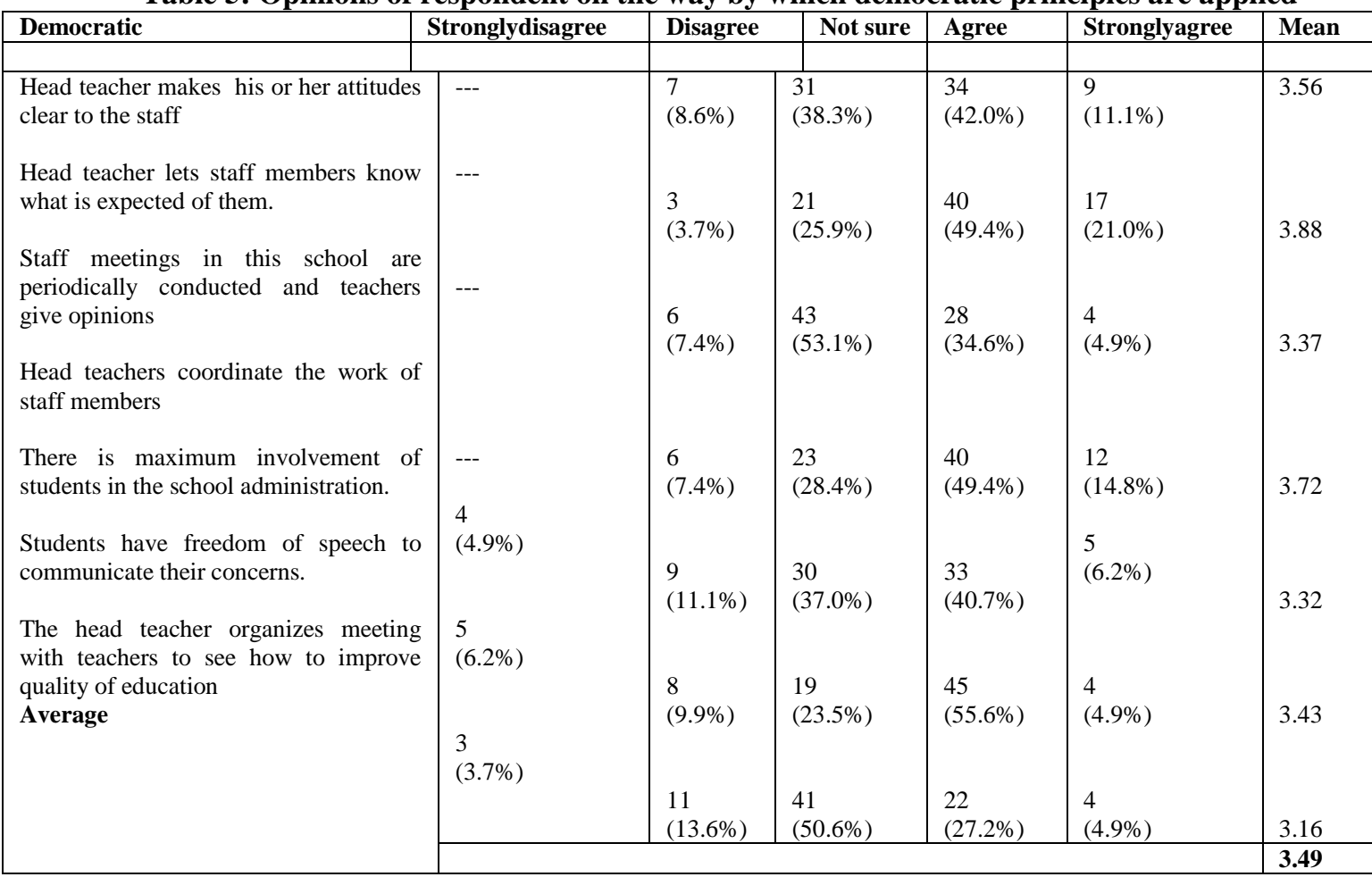

Source: Primary data 2016

Legend: 5. Strongly Agree=[4.21-500] =very high, 4. Agree $=[3.41-4.20]=$ high, 3. Not Sure $=[2.61-3.40]$ $=$ Moderate, 2. Disagree $=[1.81-2.60]=$ low 1. Strongly Disagree $=[1.00-1.80]=$ very low

Table5 shows the opinions of respondents on the way democratic leadership style is used by their head teachers. Four indicators were positively perceived by respondents in the following manner: it was provided that head teachers make their attitudes clear to their staff on the mean of 3.56 which is interpreted as very high mean and resulting from a big number of respondents who have agreed with that on the percentage of $42 \%$. Secondly, 
the respondents appreciated the way that head teachers let them to know what is expected to them considering the mean of 3.88 which is interpreted as high mean and this is in line with the large number of respondents who have agreed on the percentage of $49.4 \%$. Thirdly it was reported that head teachers in selected schools coordinate the activities of staff considering the mean of 3.72 which is interpreted as high mean and influenced by a large number of respondents who agreed with that considering the percentage of $49.4 \%$. Fourthly, participants in this study have positively perceived the way by which students are flee to provide communicate their speech and their concerns on looking on the mean of 3.43 which is interpreted as high mean.

The other democratic indicators which were used in this study were moderately perceived by respondents since their means fall in the interval of [2.61-3.40]. Those are periodic meeting for staff members and in it teachers are allowed to give their opinions, maximum involvement of students in schools administration, and preparing meetings with teachers which aim to improve the quality of education. In conclusion the average mean of 3.49 shows that head teachers in selected schools in this study lead their schools by following democratic principles. This is in line with rules provided by Ministry of Education and Government of Rwanda in general where stakeholders are to work closely with people under their management. In short interview with one director in well performing schools he provided that giving rights to teachers and students and coordinate their activities is a key for performance; every members of the community feel involved and strive for the better of the schools.

Another head teacher provided that when meetings related to quality performance are held regularly and those who worked well in past are rewarded, it influence the competition among teachers where everyone work to improve the quality of lessons by meeting with national standards.

\section{Extent of influence of autocratic leadership style in selected schools}

Autocratic leadership refers to a system that gives full empowerment to the leader with minimal participation from the followers. Yukl (1994) found that autocratic leaders tend to have the following five characteristics: they do not consult members of the organization in the decision making process, the leaders set all policies, the leader predetermines the methods of work, theleader determines the duties of followers, and the leader specifies technical and performance evaluation standards. Since this style of leadership usually only involves one person deciding, it permits quick decision-making. Although the autocratic style is relatively unpopular, in certain circumstances it can be an effective strategy, especially when the leader is short on time and when followers are not productive. Below table shows the opinions of respondents on autocratic leadership style in selected schools.

Table 6: Opinions of respondents on the extent of autocratic in selected schools

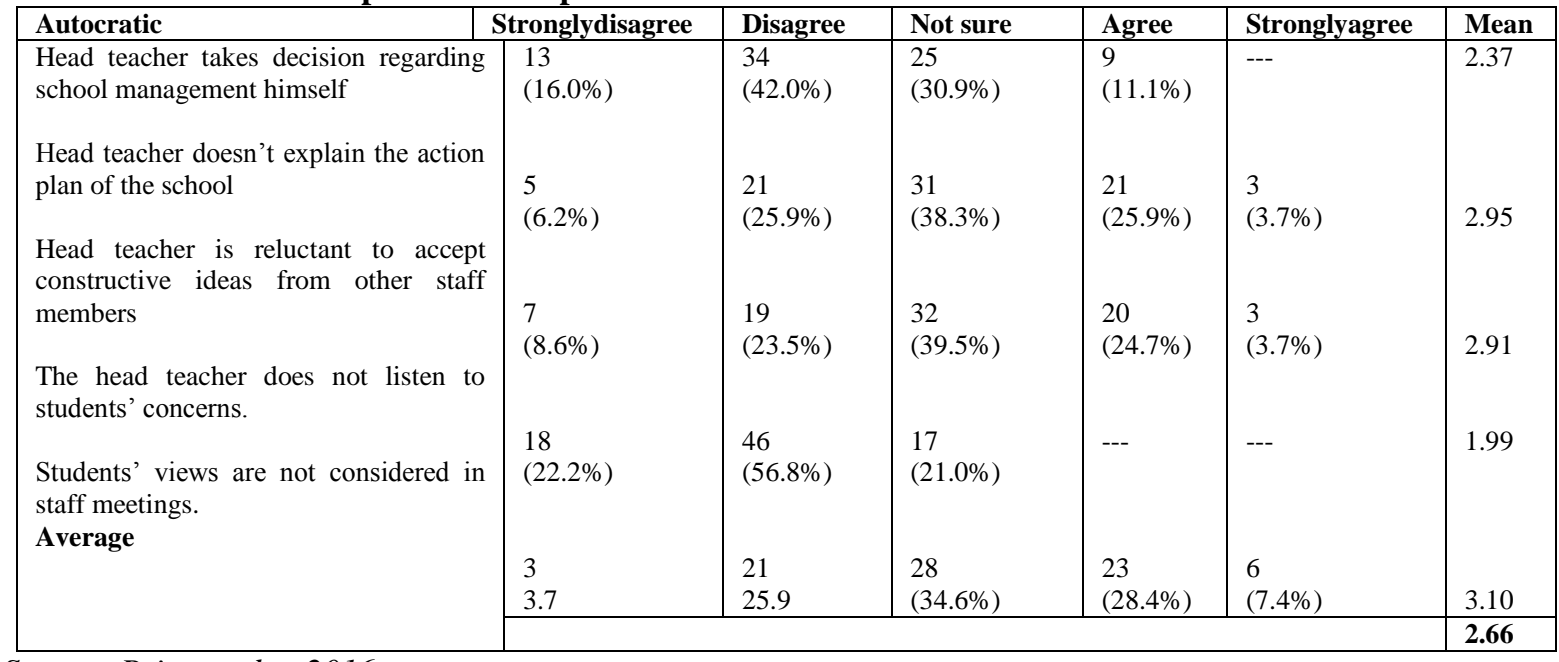

Source: Primary data2016

Legend: 5. Strongly Agree=[4.21-500] =very high, 4. Agree $=[3.41-4.20]=$ high, 3. Not Sure $=[2.61-3.40]$ $=$ Moderate, 2. Disagree $=[1.81-2.60]=$ low 1. Strongly Disagree $=[1.00-1.80]=$ very low

Considering the results in table6 a large number of autocratic indicators were moderately perceived by participants in this study. The participants revealed that sometimes meaning in moderate way head teachers don't explain the action plan of their schools since the mean is 2. 95. Secondly, it was also reported that that head teachers in selected schools are reluctant to accept constructive ideas from other staff members on the level of 2.91 which is interpreted as moderate mean. This means that some time head teachers be reluctant in accepting ideas from other staff members of their school. Another indicator of autocratic which well perceived 
in moderate manner is non-consideration of students' views in staff meeting since the mean is 3.10 which is interpreted as moderate mean. The other remaining autocratic indicators were lowly accepted by respondents. Those are taking decision regarding the management of their schools themselves on the mean of 2.37; this means that head teachers consider some staff members while they are deking decisions regarding the school management. Not understanding the concerns of students was rated on the mean of 1.99 which is interpreted as low mean; this means that head teachers take care of concerns of students and seek the appropriate way to resolve them.

In brief autocratic style is neither highly used nor lowly used by head teachers in selected schools since the average mean is 2.66 which is interpreted as moderate mean. While on field in the interview with one head teachers in selected schools provided that in some circumstances it necessary to take decision yourself in order to remind the school community what they must do for better performance.

\section{Extent of influence of laissez-faire leadership style in selected schools}

Laissez-Faire leadership is when leaders are hands-off and allow group members to make the decisions. With this style, freedoms are fully determined by group goals, techniques, and working methods. Leaders rarely intervene. Laissez-faire style is described by Hackman and Johnson (2009) as the most effective style, especially where followers are mature and highly motivated. Laissez-faire leadership style allows complete freedom to group decision without the leader's participation. Thus, subordinates are free to do what they like. The role of the leader is just to supply materials. The leader does not interfere with or participate in the course of events determined by the group (Talbert and Milbrey, 1994). However below table shows how respondents perceive the laissez-faire style in selected schools

Table7: Opinions of respondents on the extent of laissez-faire in selected schools

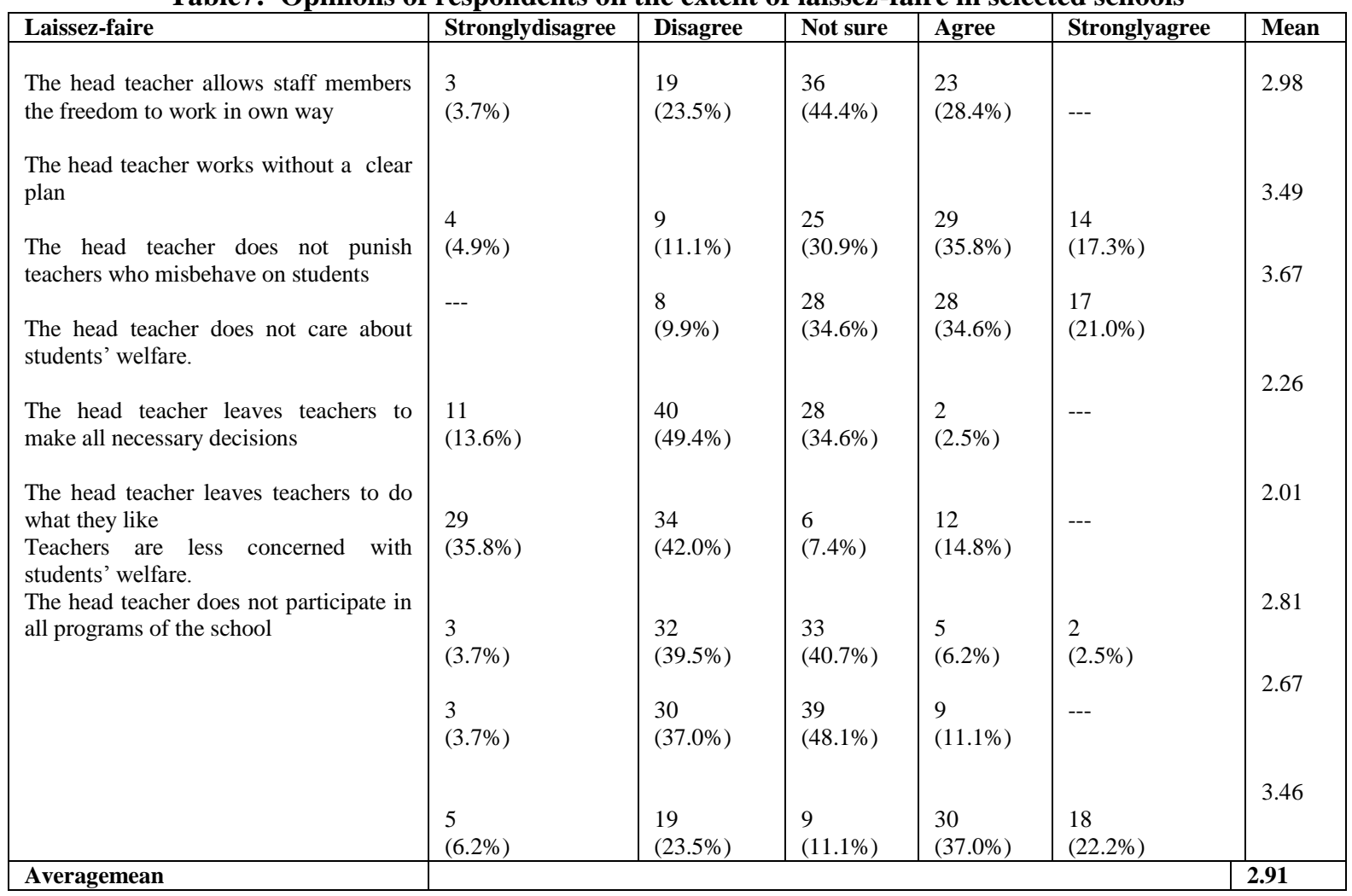

Source: Primary data 2016

Legend: 5. Strongly Agree=[4.21-500] =very high, 4. Agree $=[3.41-4.20]=$ high, 3. Not Sure $=[2.61-3.40]$ $=$ Moderate, 2. Disagree $=[1.81-2.60]=$ low 1 . Strongly Disagree $=[1.00-1.80]=$ very low

Table7 shows the opinions of respondents on indicators which were taken as laissez-faire characteristics. The respondents perceived positively the following: they revealed that head teachers work without a clear plan since the mean is 3.49. Secondly respondents reported that head teachers do not punish teachers who show misbehavior to the students on the mean of 3.67 which fall in the interval of [3.41-4.20] which is interpreted as high mean; it means it rare to see the head teacher to take a tough decision to the teacher while they are working in wrong manner. Thirdly, it was reported that head teachers in selected schools don't participate in all programs of schools on the mean of 3.46 which is interpreted as high mean. Summing all 
responses provided by respondents to each indicator of laissez-faire as one of leadership style the average mean of 2.91 shows that it's the kind of leadership that is moderately applied in selected schools.

In short the Assessment of the extent of applying leadership styles in selected schools: The specific objective of this study was to identify the level of applying different leadership styles in selected schools. Those leadership styles are transformational, democratic, autocratic, and laissez-faire. The results revealed that democratic as leadership style highly applied than the remaining leadership styles because its average mean is 3.49 which is interpreted as high mean which others are used moderately.

\section{Assessment of performance level among students in selected schools}

The second objective of this study was to examine the performance of students in selected schools. The performance was measured through the opinions of respondents like as it was done on the first specific objective. The results revealed that in selected schools they perform moderately in general but it was revealed that students hold the character of competitiveness among them.

The second specific objective of this study was to assess the performance level of students in selected public secondary schools in Gasabo district. The results on this objective were obtained using opinions methods where participants provided their responses in form of Likert scale questions. Below table shows what was provided by respondents on performance of students in selected schools in Gasabo district

Table8: Opinions of respondents on students' performance in Gasabo district

\begin{tabular}{|c|c|c|c|c|c|c|}
\hline Student performance & Stronglydisagree & Disagree & Not sure & Agree & Stronglyagree & Mean \\
\hline $\begin{array}{l}\text { The results for national examinations } \\
\text { are always good in these schools }\end{array}$ & $\begin{array}{l}6 \\
(7.4 \%)\end{array}$ & $\begin{array}{l}19 \\
(23.5 \%)\end{array}$ & $\begin{array}{l}40 \\
(49.4 \%)\end{array}$ & $\begin{array}{l}16 \\
(19.8 \%)\end{array}$ & --- & 2.81 \\
\hline $\begin{array}{l}\text { During mock examination students } \\
\text { perform well }\end{array}$ & -- & $\begin{array}{l}30 \\
37.0\end{array}$ & $\begin{array}{l}37 \\
(45.7 \%)\end{array}$ & $\begin{array}{l}13 \\
(16.0 \%)\end{array}$ & 1 & 2.81 \\
\hline $\begin{array}{l}\text { The mean for school examination is } \\
\text { high in this school }\end{array}$ & --- & $\begin{array}{l}2 \\
(2.5 \%)\end{array}$ & $\begin{array}{l}52 \\
(64.2 \%)\end{array}$ & $\begin{array}{l}25 \\
(30.9 \%)\end{array}$ & $\begin{array}{l}2 \\
(2.5 \%)\end{array}$ & 3.33 \\
\hline $\begin{array}{l}\text { There is the character of competition } \\
\text { among students }\end{array}$ & --- & $\begin{array}{l}5 \\
(6.2 \%)\end{array}$ & $\begin{array}{l}25 \\
(30.9 \%)\end{array}$ & $\begin{array}{l}37 \\
(45.7 \%)\end{array}$ & $\begin{array}{l}14 \\
(17.3 \%)\end{array}$ & 3.74 \\
\hline Students performance & & & & & & 3.17 \\
\hline
\end{tabular}

Source: Primary data 2016

Legend: 5. Strongly Agree $=[4.21-500]=$ very high, 4. Agree $=[3.41-4.20]=$ high, 3. Not Sure $=[2.61-3.40]$ $=$ Moderate, 2. Disagree $=[1.81-2.60]=$ low 1. Strongly Disagree $=[1.00-1.80]=$ very low

Table 8 shows the opinions of respondents on performance of students in selected schools in Gasabo district. It was revealed that students perform well on high mean of 3.74 in terms of competition among them. To other remaining indicators of performance which were used in this study meaning the goodness of national examination results, performance in mock exams, mean for school examination the results reveal that there is a moderate performance of students on them since their means fall in the interval of [2.61-3.40] which is interpreted as moderate mean. Those results lead to the conclusion of saying that students in selected schools performs moderately since the average mean is 3.17 which falls in the interval of moderate mean.

\section{Relationship between leadership styles and performance of students}

Using correlation method it was found that there is a significant positive relationship between transformational leadership style and performance of students. It means that as the transformational leadership style is highly used as the students perform better. A positive relationship also was found between democratic style and performance of students but finally it was not found to be statistically significant. To the other remaining two leadership styles the results found that there is a negative relationship between them performance of students but not statistically significant.

\section{Conclusion}

This study was aiming to examine the influence of leadership styles applied by head teachers on performance of students in selected schools of Gasabo district. The general results found that the most influential leadership style on performance of student is transformational one even if it was found that it is applied moderately comparing to democratic which was also found to influence the performance of students positively even it was found not to be statistically significant. 


\section{Recommendations}

The study found out that the head teachers in the district applied various leadership styles where majority applied democratic, while a few applied authoritarian and laissez fairer leadership styles. According to the findings of this study it was revealed that transformational leadership style is more influential to performance of students in selected schools. But this was found not to be highly applied by head teachers in selected schools. To this head teachers are recommended to increase the way by which they apply this style by doing the following: Creating clear vision regarding the future of their schools, and inspiring the confidence by valuing their arguments. The head teachers must be eager to achieve the vision of their schools. Beside those, the head teachers are highly recommended to apply all principles of transformational leadership style effectively as they can in form of inspirational motivation, intellectual simulation, and individual consideration.

The findings also revealed that in Gasabo district student in selected schools perform moderately and to this the head teachers are recommended to do the following apart from strengthening transformational leadership style:Identify other challenges of efficient performance of students and seek effective solutions to them, Control and monitoring where teachers deliver lessons according the national curriculum, Reminding parents that are the first educators and key to performance of their students by delivering to them all facilities and advises for their future.The Ministry of Education should do the following: to identify the reasons behind the perennial poor performance of schools in national exams in Gasabo District since this study ruled out the leadership styles as the plausible cause of the poor performance. To identify the level of pupils' preparedness for the national exams. It is most likely that dimension can help to find out the extent to which pupils are ready and well prepared for exams. To organize motivational talks to the candidates before they sit for national exams. It is envisaged that this strategy can probably help to prepare them psychologically and boost their morale.

\section{References}

[1] Armstrong, M. (2004). Handbook of human resource management practice (9th ed.). London: Kogan Page.

[2] Avolio, B. J., \& Bass, B. M. (2002). Manual for the Multifactor Leadership Questionnaire (Form 5X). Redwood City, CA: Mindgarden.

[3] Bell, A. (2007). Using vision to shape the future. Leader to Leader, 2007(45), 17-21.

[4] Cole, G. (2004). Management Theories and Practices, 6th ed. London: Thomston Publication.

[5] Cole, G. (2002). Personnel and human resources management. London : Thomson Learning.

[6] Finn, C. E. (2002). Bureaucracy and School Leadership. Retrieved November 20, 2017 from http//www.google.com.

[7] Hurley, J. C. 2001. The Principalship: Less May Be More. Retrieved November 20, 2017 from http//:www.google.com

[8] Kendra, C. (2013). What is Laissez-Faire Leadership? Retrieved November 20, 2017 from http:// www.psychology.about.com/od/leadership/f/lasissez-faire-leadership.htm

[9] Muli, M. (2005). Effects of head teachers' management styles on performance in Phyisics at KCSE examinations in Mutomo division, Kitui district. Nairobi: unpublished M.E.d project, University of Nairobi.

[10] Mutai, K. (2000). 2000 How to write quality research proposal: A complete simplified recipe. New Delhi: ND: Thelley Publications.

[11] Mwalala, D. B. (2007).The Influence of Head Teachers' Leadership Styles on K.C.S.EPerformance in Public Secondary Schools in Taita District, University of Nairobi

[12] Nganizi,D. (2015). principal's leadership styles and students academic performance in Nine years basic education schools in Rwanda. Kicukiro: un published Thesis.

[13] Omolayo, B. (2009). Effects of leadership styles on job related tensions and psychological sense of four organizations . Lagos.

[14] Orodho, A. (2004). Statistics Made User Friendly for Education and Social Science Research. Lagos: Masora Publishers.

[15] Sashkin, M. \& Sashkin, M. 2003. Leadership That Matters. San Francisco: BerrettkoehlerPublishers Inc.

[16] Sheikh, A.G. (2001. Leadership Styles As Viewed by Secondary School Head Teachers of Lahore City. Institute of Leadership and Management Lahore Affiliated with HamdardUniversity, Karachi Pakistan. Master thesis in education Studies of Management andOrganization, 19(1), 6-27.

[17] Schermerhorn, J.R., Hunt, J. G. and Osborn, R. N. (2000). organizational Behavior. 7th edition. New York : John Wiley and sons Inc.

[18] Sushila,B. (2004).Management and evaluation of schools. Nairobi;Oxford University Press.

[19] Tableman, B. (2004). school climate and learning: Best practice brief (No.31). East lansing, MI: Michigan state UniversityCommunity Partinership.

[20] Wilmore, E. L. (2002). Principal Leadership. California: Corwin Press Inc.

[21] Yukl, G. A. (2005). Leadership in organizations (6th ed.). Upper Saddle River, NJ: Eye On Education, Inc. 